\title{
Using Case-Based Reasoning To Solve Water Purification Problems
}

\author{
Nita Andriani Safitri, Saepudin Rahmatullah, Yudi Dirgantara, Ida Farida \\ Mathematics and Science Education Department. Faculty of Tarbiyah and Teacher Training \\ UIN Sunan Gunung Djati Bandung \\ Bandung, Indonesia \\ farchemia65@uinsgd.ac.id
}

\begin{abstract}
This study is based on the importance of students developing skills to solve daily life problems related to dirty water purification. Through case-based reasoning, students solve problems by applying basic chemical concepts. The application of case base reasoning is performed using one shot case study design. The subjects were 37 students of high school in Bandung. The learning objectives of problem solving skill developed include identifying and formulating problems, collecting data, formulating hypotheses, testing hypotheses, conducting experiments and drawing conclusions. The students' problemsolving skill data were obtained from performance tasks, assessment rubrics and test. The result showed that the four stages of learning (retrieve, reuse, revise, and retain) can be done well to develop problem solving skill and overall students can develop problem solving skill with good category.
\end{abstract}

Keywords—case based reasoning; chemistry learning; problem solving skill; water purification

\section{INTRODUCTION}

In order to face the challenges of life in the 21 st century, learning must be aimed at equipping students with high-level thinking skills [1]. The learning process should be relevant to the shift of learning paradigm from the transfer of knowledge to the transfer of learning. For that, the learning process should facilitate students with various challenges that are close to aspects of everyday life of the students. Based on this paradigm, learning chemistry is aimed at developing students' thinking skills to solve everyday life problems it faces, not just to meet academic achievement [2].

As a part of natural science, Chemistry provides an explanation of the natural phenomena associated with the structure, properties, matter changes and energy changes that accompany the changes of matter. In essence, studying chemistry is an attempt to understand the Kauniyah verses or the Word of God that is expressed in natural phenomena. Therefore, it is very important to develop students' thinking skills about natural phenomena, as stated in Al Quran Surah Ali Imran Verses 190-191.

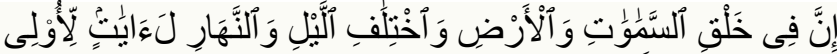

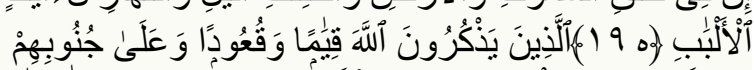

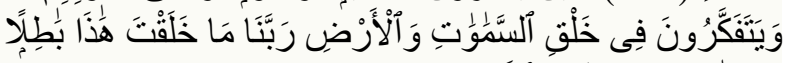

$$
\begin{aligned}
& \text { 1918) }
\end{aligned}
$$

\section{Meaning:}

"Indeed, in the creation of the heavens and the earth and the alternation of the night and the day are signs for those of understanding. Who remember Allah while standing or sitting or [lying] on their sides and give thought to the creation of the heavens and the earth, [saying], "Our Lord, You did not create this aimlessly; exalted are You [above such a thing]; then protect us from the punishment of the Fire "

One of the problems that students often encounter in certain areas is the difficulty of getting water that is suitable for daily use. Through chemistry learning, students need to be equipped with skills on how to clear water to overcome the difficult problem of getting clean water. Purification of water is a technical effort undertaken to produce drinking water products in accordance with water quality standards physics and chemically appropriate [3]. Purification of water can be done by adding chemicals such as alum and chlorine. Water purification can also be performed using a filtration system using a variety of filter materials, or incorporating a water purification chemically and physically [4]. With many cases requiring application of chemical concepts in the environment (such as dirty water cases), students are expected to find the right solution and be able to develop problem-solving skills.

The case of dirty water purification is relevant to one of the study materials in the Chemistry curriculum, namely the concept of colloids. Generally, there is a tendency to study the concept of colloids emphasizing low-level cognitive abilities. In addition, achievement of student learning outcomes takes precedence in the ability to remember concepts and academic value acquisition [5]. This resulted in students learning the concept of colloids less meaningful and unpleasant.

Therefore, it is necessary to develop an interesting learning approach and can facilitate the students to develop thinking ability according to the case they face in daily life.

Case based reasoning approach is one of the alternative approaches that can be used to achieve the goal [6]. Through Case based reasoning students develop problem-solving skills by utilizing prior experience to solve new problems. Case based reasoning approach has been widely used computer technology work system which is then adapted to diagnose clinical cases in the medical field [7]. 
The problem-solving approach using Case-based reasoning allows also to be adapted for learning in chemistry in the classroom. In this case, students are asked to analyze the similarity of a case or some other case, then make a reason to obtain new problem-solving based on the previous case [8]. The results of the study [9] show that Case Based Reasoning (CBR) learning can improve students' ability to solve problems. In the learning of chemistry, CBR stage modification is done by combining it with inquiry stage (and Jigsaw type cooperative learning method).

This paper describes the results of the problem-solving skill analysis that students develop through case-based reasoning learning.

\section{METHOD}

The method used in this research is a class research method with one shot case study design. The subject of research is 37 students at one of high school in Bandung.

Student activity in learning is facilitated by using Jigsaw Type cooperative method. The teacher assigns the student to complete the worksheet on the dirty water case. In the worksheet there are four cases of dirty water caused by different impurity materials. Each student in a group gets different tasks according to the questions contained in the worksheet. Each member of the group who is assigned the same task as another group, gathered in a new group to discuss the completion of their duties.

At each learning stage, student learning activities are guided through a worksheet. After student learning is given a test to measure problem-solving skills. The problem-solving skills indicators developed in the lesson are identifying and formulating the problem; collecting data and information / required information; formulating hypotheses, assessing hypotheses; conducting experiments or testing hypotheses, and drawing conclusions [10]

Student activity and performance during learning are observed and assessed using the assessment rubric. The data obtained from the research results are processed and analyzed descriptively and interpreted for the conclusion.

\section{RESULT AND DISCUSSION}

Problem-solving skills are the main objectives of learning using a case-based reasoning approach. There are four stages of case-based reasoning learning conducted to train students to have problem-solving skills, namely the retrieve, reuse, revise, and retain stages [11].

At the beginning of learning, teachers explain the purpose of learning colloid role in daily life. Students after learning are able to: 1) analyze problems based on the discourse of colloidal phenomena in everyday life, (2) design solutions based on problems on colloidal material and 3) apply experiments related to colloidal principles. Before the teacher gives the worksheet, the students are told to sit in groups according to the group specified by the teacher. Students are divided into four heterogeneous groups. The four groups are called the original group. The teacher gives the worksheet to the original group containing four cases of dirty water purification with different causes. Each student in each group of origin is assigned different tasks according to the questions contained in the worksheet. Group members from other groups who have studied the same task come together in a new group called expert groups to discuss their work. Case-based reasoning is done in four stages of learning; retrieve (pick up the same problems), reuse (reuse the information to solve new problems), revise (revisiting the solution) and retain (steeped in the solution).

In the first stage (retrieve), students develop the ability to identify and formulate problems regarding new cases based on the previous case resolution. To achieve this, the teacher provides an example of a case concerning the process of sugar bleaching. The case of the sugar bleaching process is a case different from the case of the student to solve, but the case has a similar settlement principle. Students are expected to find solutions based on sugar bleaching case.

There are four different problems that are given to the students. Problems are presented in the form of discourse and a number of guiding questions to develop problem-solving skills.

The first discourse that is the case of dirty water that often changes color from colorless to color like red ground. The second discourse about the clean water crisis due to damaged river water embankment. The third discourse on the difficulty of getting clean water and residents still use dirty water for daily needs. The fourth discourse about the supply of clean water from regional drinking water company turned into brown color mixed with mud.

The selection of cases is in accordance with the material that will be given to students and related to daily life. In addition, cases must also be applicative. At the time of reading this discourse students are expected to explore information about the case by answering questions, about: 1) the impact of colored water cases on the environment and health 2) ways to overcome the colored and odorous water and 3) the function of the addition of activated charcoal, alum, moringa seeds and ash of rice husk. These questions lead students to get problem solving through tracing information from various sources.

At the reuse stage, students use the information they have obtained to determine the action to be taken in solving the dirty water case. The action they planned was asked to be written in the description and scheme of the water purification experiment procedure. Therefore, every case of dirty water caused by different impurities, the procedure to purify dirty water also use different materials. There are four different water purification material according to the case that they are dealing with, which uses activated charcoal, rice husk, Moringa seed powder and alum.

On stage revise, students restate the problem and hypothesis formulation in accordance with the design of the initial solution has been prepared. Teachers review the student design solutions and check whether it is appropriate and relevant weeks to solve the problems faced by each group. Furthermore, each group conducted an experiment to test the hypothesis. 
At the retain stage, students explore the solution of the problem of dirty water by presenting the findings that have been obtained to be confirmed simultaneously with the teacher. Each group of students presented their work and other students responded to the group that presented it.

The performance of the students in the group at each stage is assessed using the assessment rubric. The following table 1 presents the results of the analysis of problem solving skills developed by each group of students.

TABLE I. DEVELOPMENT OF PROBLEM SOLVING SKILLS FOR EACH GROUP ON THE LEARNING PROCESS

\begin{tabular}{|c|c|c|c|c|c|c|c|}
\hline \multirow{2}{*}{ Group } & \multicolumn{6}{|c|}{ Problem solving skill indicators } & \multirow{2}{*}{ Mean } \\
\cline { 2 - 7 } & $\mathbf{1}$ & $\mathbf{2}$ & $\mathbf{3}$ & $\mathbf{4}$ & $\mathbf{5}$ & $\mathbf{6}$ & \\
\hline I & 80 & 92 & 67 & 75 & 83 & 92 & 81.5 \\
\hline II & 82 & 100 & 63 & 67 & 85 & 93 & 82 \\
\hline III & 85 & 100 & 47 & 73 & 87 & 80 & 77 \\
\hline IV & 82 & 93 & 52 & 67 & 81 & 93 & 78 \\
\hline Mean & 82 & 96 & 57 & 70.5 & 84 & 89.5 & 80 \\
\hline
\end{tabular}

Information:

$1=$ Identifying and formulating the problem

$2=$ Search the library for solutions

$3=$ formulate hypotheses and design solutions

$4=$ designing an experimental procedure,

$5=$ collect data through experiment

$6=$ conclude

Based on Table 1 it can be seen that students' ability in general in terms of finding solutions to problem solving is good (mean value 80), it shows that case-based reasoning learning can develop problem solving skills with good category. Lowest skills on the ability to formulate problems, design solutions and design experimental procedures. Some students have difficulty in finding experimental procedures on water purification. Students also look somewhat difficult in designing experiments.

This is presumably because of the conceptual chemistry conceptual concept, the students accustomed to assign only summarize and memorize the concepts. In addition, when performing the experiment, students use a detailed laboratory procedure (type of cook book). They are not accustomed to the process of designing themselves based on the problems faced. Therefore, it is necessary to continue guidance and direction so that students can design procedures as expected. Furthermore, by providing challenges and cases in daily life students are expected to have problem-solving skills [12].

Problem solving skills students are assessed on the answer to the problem-solving skills tests. Indicators that measure problem solving skills using explanation test that measures five indicators are: identify and define problems, collect data, formulate hypotheses, assess hypotheses and conducting experiments.
The mean value of the problem-solving skill test of each indicator for the student achievement group is presented in table 2 .

TABLE II. AVERAGE VALUE OF PROBLEM-SOLVING SKILL TEST FOR EACH STUDENT ACHIEVEMENT GROUP

\begin{tabular}{|c|c|c|c|c|c|c|}
\hline \multirow{2}{*}{$\begin{array}{c}\text { Student } \\
\text { achievement } \\
\text { group }\end{array}$} & \multicolumn{5}{|c|}{ Problem solving skill indicators } & \multirow{2}{*}{ Mean } \\
\cline { 2 - 6 } & 1 & 2 & 3 & 4 & 5 & \\
\hline High & 75 & 75 & 58 & 75 & 92 & 75 \\
\hline Middle & 61 & 54 & 67 & 70 & 82 & 67 \\
\hline Lower & 58 & 50 & 67 & 67 & 92 & 67 \\
\hline Average & 65 & 60 & 64 & 71 & 89 & 70 \\
\hline
\end{tabular}

Information:

$1=$ Identify and formulate the problem

$2=$ Collecting Data

$3=$ Formulating Hypotheses

$4=$ Assessing Hypothesis

$5=$ Conduct experiment

Based on table 2 it can be seen that overall achievement of problem solving skills after learning is good (average score $=$ 70).

The lowest mean value is obtained on the problem-solving indicator: collect the data (mean value $=60$ ), while the highest score on the problem-solving skill indicator: carry out the experiment or test the hypothesis of 89 . Based on the acquisition, the student has been able to develop his thinking skills in connecting previous cases which is almost the same as the new problem. Students have tried to find a solution by modifying the way or principle to fit can solve the new case. However, problem solving skills still need to be trained in learning. Teachers need to further present learning that challenges students to develop thinking skills.

\section{CONCLUSION}

Based on the results of research on the application of casebased reasoning learning which consists of four stages: retrieve, reuse, revise and retain can develop students' skills in solving the case of purification of dirty water with very good category (mean value $=80$ ). The achievement of student problem-solving skills after learning shows good category (mean score $=70$ ). Thus case-based reasoning learning can provide an effective learning situation and assist students in developing students' skills in solving real-life problems regarding dirty water purification. 


\section{REFERENCES}

[1] I.W. Redhana, "Menyiapkan Lulusan FMIPA yang Menguasai Keterampilan Abad XXII," presented at the SemNas FMIPA Undiksha V, 2015.

[2] I. Farida, "Profil Keterampilan Argumentasi Siswa Pada Konsep Koloid Yang Dikembangkan Melalui Pembelajaran Inkuiri Argumentatif," Edusains, vol. 6, no. 1, pp. 31-40, 2014.

[3] S. Alamsyah, Merakit Sendiri Alat Penjernih Rumah Tangga. Jakarta: Kawan Pustaka, 2006

[4] O. Untung, Menjernihkan Air Kotor. Jakarta: Puspa Swara, 2008.

[5] S. Sari, R. Ratnasari, and I. Farida, "Pengembangan Sikap Kreatif Siswa Pada Praktikum Penjernihan Air," EduChemia J. Kim. Dan Pendidik., vol. 1, no. 2, pp. 124-136, 2016.

[6] P.J. Van Den Brink, J. Roelsma, E. Van Nes, M. Scheffer, and T. C. Brock, "Perpest Model, A Case-Based Reasoning Approach To Predict Ecological Risks Of Pesticides," Environ. Toxicol. Chem., vol. 21, no. 11, pp. 2500-2506, 2002.

[7] S.K. Pal and S.C.K. Shiu, Foundation of Soft Case-based Reasoning. New Jersey: Wiley Intersience Pub, 2004.

[8] S. Mulyana and S. Hartati, "Tinjauan Singkat Perkembangan CaseBased Reasoning" in Seminar Nasional Informatika, 2009, vol. 2009, no. semnasIF, pp. 17-24.

[9] Y.A. Gerhana, C. Slamet, and U. Saripudin, "Model Pembelajaran CaseBased Reasoning Pada keterampilam Mendiagnosa Permasalahan Perangkat yang Tersambung dengan Jaringan Lokal di SMK TKJ," J. ISTEK, vol. VIII, no. 1, pp. 73-85, 2014.

[10] M. Tawil and L. Liliasari, Berpikir Kompleks dan Implementasinya dalam pembelajaran IPA. Makasar: Badan Penerbit UNM, 2013.

[11] S. Mulyana and S. Hartati, "Tinjauan Singkat Perkembangan Case Based Reasoning," presented at the Seminar Nasional Informatika, 2009, vol. 2009, pp. 17-24.

[12] I.W. Redhana, "Model Pembelajaran Berbasis Masalah untuk Peningkatan Keterampilan Pemecahan Masalah dan Berpikir Kritis," J. Pendidik. Dan Pengajaran, vol. 1, no. 46, pp. 76-86, 2013. 